\title{
Reframing E-Government Development Indices with Respect to New Trends in ICT
}

\section{Renáta Máchová, Martin Lněnička ${ }^{1}$}

\begin{abstract}
E-government readiness is an important indicator of the quality of a country's technological and telecommunication infrastructure and the ability of its citizens, businesses and governments to adopt, use and benefit from modern technologies. To measure and compare selected countries, a lot of benchmarking and ranking indices have been introduced since the beginning of the century. With the increasing importance of trends such as cloud computing, open (big) data, participation tools or social media, new indicators and approaches need to be introduced in the measuring of the e-government development, and the existing indices should to be updated, redefined and restructured. Therefore, this article explores the structure of the existing e-government development indices to show the main indicators and trends. Then, it proposes and implements a new framework to evaluate e-government development using these new trends in ICT. It also examines and compares a basic background on the e-government development, benefits and risks of cloud computing, open (big) data and participation tools in the public sector. Based on the newly proposed framework, the e-government development index is calculated for each EU Member State to clearly identify the indicators to have an influence on the e-government development. In the last part, these results are compared to the already existing indices to validate the conformity of the rank methods using Kendall rank correlation coefficient.
\end{abstract}

Key words: e-government, benchmarking framework, cloud computing, open (big) data, participation, e-government development index, European Union

JEL Classification: C43, H11, H83, L86

Received: 19 August 2015 / Accepted: 24 October 2015 / Published: 21 December 2015

\section{Introduction}

Although many e-government policies, programs, and services such as e-procurement, e-tax or e-voting have been implemented in various countries, the priorities of the egovernment development still focus on the resource allocation demand to be justified. For example, the necessity of cloud services and the application and integration of na-

\footnotetext{
${ }^{1}$ Department of System Engineering and Informatics, Faculty of Economics and Administration, University of Pardubice, Studentská 84, 53210 Pardubice, renata.machova@upce.cz, martin.lnenicka@gmail.com
}

( 2015 by the authors; licensee Review of Economic Perspectives / Národohospodářský obzor, Masaryk University, Faculty of Economics and Administration, Brno, Czech Republic. This article is an open access article distributed under the terms and conditions of the Creative Commons Attribution 3.0 license, Attribution - Non Commercial - No Derivatives. 
tional open and big data are increasingly popular (Al-Khouri, 2011; Chu and Sun, 2013, Waseda University, 2015).

Modern Information and Communication Technologies (ICT) change the way that government develops, manages and implements technology, and create another challenge for governments to operate more efficiently and transparently to provide better, cheaper and faster services to the public and to facilitate the participation of citizens and businesses in the governance. Opening data may allow citizens and businesses to analyze various datasets and understand what governments spend public resources on. They also strengthen inclusiveness by proactively providing access to information, thereby increasing transparency and creating opportunities for citizens, businesses and civil society organizations to reuse these data in new ways (OECD, 2015). Big data then create usable insight and value from large amounts of structured and unstructured data coming from many different sources and with differing dynamics. The intersection of big and open data is as much about integrating multiple data sources, e.g. on the local, national or international level of the public sector (Marton, Avital and Jensen, 2013; Tsiavos, Stefaneas and Karounos, 2012). The combination of size, multiple sources, and unstructured data then presents the problem of having sufficient computing power to process these data. This problem may be then solved using cloud computing (Alshomrani and Qamar, 2013; Cellary and Strykowski, 2009; Hashemi, Monfaredi and Masdari, 2013; Khan et al., 2011; Zwattendorfer et al., 2013). Cloud computing is like a service processing mechanism which is web-based, whereby shared resources of software and data are provided to computers and other related devices (such as smart-phones and other mobile devices), and the user is just accessing selected public service available on the cloud and getting the solutions to his queries (Mukherjee and Sahoo, 2010).

The idea of using new technologies to support, enhance, expand, or re-invigorate democratic practices and support development, design and delivery of high quality and effective public services is not novel (Dawes, Pardo and Cresswell, 2004; Krishnan, Teo and Lim, 2013). Many governments across the world are constantly transforming into the new forms of e-government to increase their performance and reinforce and maintain their positions in the global competition (Gupta and Jana, 2003; Hansen, Hvingel and Schrøder, 2013). E-government is an important application field for the transformations that governments are undergoing and will continue to undergo in the following decades. In recent years, many citizen centric portals and applications were implemented by governments of various countries (Van der Waal et al., 2014). Moreover, there is currently a trend to transform e-government by the means of opening government data to the public (Hyland and Wood, 2011). As government develops e-government systems to offer such enhanced services to the citizens, further assessment efforts are required to measure the effectiveness of the e-government development (Kao, 2015; Siskos, Askounis and Psarras, 2014; Waseda University, 2015). These measurements are a foundation for implementing effective e-government plans that supply significant knowledge and information sources for policy and decision making (Rorissa, Demissie and Pardo, 2011).

An effective e-government development is based on various international, national or local initiatives that require information about the organizational and technical infrastructures, as well as information about the needs of citizens and businesses (Rorissa, 
Demissie and Pardo, 2011). E-government benchmarking is being conducted by various organizations, but its assessment is sometimes based on a limited number of indicators and does not highlight the multidimensional nature of the electronically provided services (Siskos et al., 2013). Reliable, relevant and valid e-government measurement and benchmark can offer crucial notices to point policy makers and practitioners in the right direction (Nardo et al., 2008).

The main objective of this article is formulated in the context of the considerations mentioned above. It offers a solution to deal with the new trends and challenges in ICT through the comparison of the e-government development frameworks and indices. It contains an approach to propose a new framework focusing on the new trends in ICT. The proposed framework, which is represented by the e-government development index, is then validated and applied to the Member States of the European Union (EU).

\section{Literature review and theoretical background}

\section{E-government frameworks, indices and rankings}

E-government is the use of ICT and its application by the government to streamline and integrate workflows and processes, to effectively manage data and information, enhance online public service delivery, as well as expand communication channels for engagement and empowerment of people (United Nations, 2014). The e-government development is studied by building frameworks, benchmarks and models of its stages (Yildiz, 2007). Al-Khouri (2011) studied many of the e-government initiatives around the world and showed that very few of them have succeeded in achieving the outcomes they initially hoped to deliver. Chu and Sun (2013) studied selected e-government development rankings and reports released by influential international centers to summarize a list of promising e-government research topics. Their results imply that optimal goal of egovernment is to pursue or create more public values that will bring varieties of utility for multi-stakeholders, and also take social equity into account. This fact was already mentioned by Gupta and Jana (2003), and proves that the goals are still the same, only the tools and technologies change.

The need for continuous monitoring and assessment of e-government progresses has led to development of relevant frameworks and models (Siskos, Askounis and Psarras, 2014). In the course of the last 15 years, several frameworks have been introduced in order to help assess opportunities and challenges facing e-government initiatives (Máchová and Lněnička, 2015). Some frameworks are based on measurable characteristics of the entities, other use one or more subjective measures, a few employ a combination of both. Frameworks based on grounded and broadly applicable measures tend to attract fewer criticisms. Those based on subjective measures often result in controversies and complaints, especially from those countries or institutions who believe that they were not characterized accurately (Rorissa, Demissie and Pardo, 2011). These frameworks are conducted predominantly by organizations and can be distinguished in three categories (Siskos, Askounis and Psarras, 2014): governmental (national or international level such as the EU), academic (researchers and universities such as the Waseda University) and independent organizations (private trustworthy companies or organizations). Despite the general agreement on the value of benchmarking e-government and ranking 
countries based on their e-government service delivery, controversy still exists over the best methods and practices. One critic of benchmarking based on web measures dismissed it because: (1) it does not account for internal re-organization, national context and priorities, and the users' perspective, (2) it is not reliable (different benchmarks produce different ranks even for the same country) and the methodologies used are not revealed by individuals and organizations conducting the benchmarking, and (3) the stages of e-government service development used in the computation of these benchmarking indices often do not reflect actual e-government service use and the progress of demand, i.e. ICT productivity paradox (Codagnone and Undheim, 2008). E-government benchmarking methods also become more problematic, and the critics' views more telling, when they move beyond objective, supply-side criteria (e.g., services offered via websites) to include calculated indices and subjective indicators (Rorissa, Demissie and Pardo, 2011).

There is a great number of indices and rankings. Some of them have become frequently cited and used as benchmarks, guiding the debate as well as governments' investments in the e-government development (Grönlund, 2011). The basic idea of these evaluations is first to find the criteria which reflect the performance of e-government and then design a scoring system for each of these criteria to transform the data collected from noncommensurable criteria into numbers that have the same basis for comparison. Weight, which represents the relative importance, is then assigned to each criterion to obtain a weighted sum to represent the overall performance of each country with regard to the e-government development. All countries are then ranked based on the weighted sum. Countries with low ranks should then be able to make appropriate improvements by identifying the criteria with low scores (Kao, 2015). However, the range of tools uses widely varying definitions and different methods for measurement of the e-government development. Furthermore, there are also some differences in the indicators and their weights from index to another depending on the importance of that indicator from the point view of the organization, that construct the model. In general, however, most of the frameworks and models tend to measure the readiness of a country according to how it is capable to deal with infrastructure and technology, people and human skills, accessibility and connectivity, and transparency (Yildiz, 2007; Mohammed and Ibrahim, 2013; Rorissa, Demissie and Pardo, 2011; Siskos et al., 2013). Some other similarities applicable to all measurements are security or the overall level of education and business sophistication.

Composite indices are much easier to interpret than trying to find a common trend in many separate indicators (Nardo et al., 2008). However, their development and use can be controversial. These indices are easily and often misinterpreted by users due to a lack of transparency as to how they are generated and the resulting difficulty to truly unpack what they are actually measuring (OECD, 2015). Furthermore, if they are poorly designed, they risk distorting government policies as countries may chase the benchmark rather than looking at real local and national needs (Bannister, 2007). Bannister (2007) also claims that benchmarks may have limited practical meaning, but they may have a huge impact on political decision-making. Therefore, to maximize the acceptability of results, rankings should be supported by well understood and clarified frameworks and indices as well as transparent computational procedures to maximize their acceptability by the governments and the scientific community (Rorissa, Demissie and Pardo, 2011). 
Furthermore, the outcomes of benchmarks need to be interpreted sensibly and it is always necessary to be aware of the risks of their politicization (Bannister, 2007).

In the EU, there is a series of the EU E-government Benchmarking reports (EUBR). This annual exercise started in 2001, and the 2015 report (European Commission, 2015) is the twelfth measurement. The number of the countries participating in the report increased from 17 (EU15, Iceland, Norway) in the first report from 2001 to 33 (EU28, Iceland, Serbia, Norway, Switzerland and Turkey). These reports are mostly focused on the best performing countries that have implemented the most mature e-government services. There is no single ranking, but more rankings based on the measured services. Also the weights or even indicators in the same model may change over the time for different reasons, the most important, emerging new technology or paradigm. The last report is then based on the E-government Benchmark Framework 2012-2015 (European Commission, 2015). In a global perspective, frequently cited indices include the United Nations' (UN) E-government rankings: the E-government Development Index (EGDI) and the E-participation index (EPI); the Economist Intelligence Unit's (EIU) Egovernment readiness and digital economy rankings; the Waseda E-government ranking; the World Economic Forum's (WEF) Networked Readiness Index (NRI) and the International Telecommunication Union's (ITU) ICT Development Index (IDI). Shortly after 2010, new indices to the e-government development research were added, e.g. the Asia Cloud Computing Association's (ACCA) Cloud Readiness Index (CRI), Business Software Alliance (BSA) Global Cloud Computing Scorecard, the Web Index and the Open Data Barometer (ODB) index produced by the World Wide Web Foundation (W3F), the OURdata Index by the Organization for Economic Co-operation and Development (OECD) or Open Knowledge Foundation's (OKF) Global Open Data Index (GODI).

Table 1 Comparison of the most recent indices

\begin{tabular}{|c|c|c|c|c|c|c|}
\hline \multirow[b]{2}{*}{ Index's name } & \multirow{2}{*}{$\begin{array}{l}\text { Organization's } \\
\text { name }\end{array}$} & \multirow{2}{*}{$\begin{array}{l}\text { First } \\
\text { report } \\
\text { from }\end{array}$} & \multirow{2}{*}{$\begin{array}{l}\text { Last } \\
\text { report } \\
\text { from }\end{array}$} & \multirow{2}{*}{$\begin{array}{c}\text { Number } \\
\text { of } \\
\text { reports }\end{array}$} & \multicolumn{2}{|c|}{ No. of countries covered } \\
\hline & & & & & $\begin{array}{c}\text { By the first } \\
\text { report }\end{array}$ & $\begin{array}{c}\text { By the last } \\
\text { report }\end{array}$ \\
\hline BSA index & BSA & 2012 & 2013 & 2 & 24 & 24 \\
\hline CRI & ACCA & 2011 & 2014 & 3 & 14 & 14 \\
\hline EGDI & UN & 2003 & 2014 & 7 & 191 & 193 \\
\hline EIU index & The Economist & 2000 & 2010 & 11 & 60 & 70 \\
\hline EPI & UN & 2003 & 2014 & 7 & 191 & 192 \\
\hline EUBR & EU & 2001 & 2015 & 12 & 17 & 33 \\
\hline GODI & OKF & 2013 & 2014 & 2 & 60 & 97 \\
\hline IDI & ITU & 2009 & 2014 & 6 & 154 & 166 \\
\hline NRI & WEF & 2002 & 2015 & 14 & 75 & 143 \\
\hline ODB & W3F & 2013 & 2015 & 2 & 77 & 86 \\
\hline OURdata Index & OECD & 2015 & 2015 & 1 & 30 & 30 \\
\hline Waseda index & $\begin{array}{l}\text { Waseda } \\
\text { University }\end{array}$ & 2005 & 2015 & 11 & 23 & 63 \\
\hline Web index & W3F & 2012 & 2014 & 3 & 61 & 86 \\
\hline
\end{tabular}

Source: Máchová and Lněnička (2015) 
A comprehensive comparison and taxonomy of benchmarking frameworks can be found e.g. in Bannister (2007). The most recent description of the progress of these frameworks' structure in the world can be found in Máchová and Lněnička (2015). A summary of the selected indices is then shown in the Table 1.

Most of these international organizations also investigate the global trends of ICT, develop economic competitiveness and e-government development indices, and select the best practices to provide countries with strategic suggestion (Chu and Sun, 2013). The global trends of the e-government development identified in the UN's latest report are cloud computing, social media, open (big) data and data analytics, multichannel approach and service delivery (one-stop portals), mobile government and related applications, helping governments go green and facilitating effective disaster management (United Nations, 2014). ITU attempts to highlight the importance cloud computing, social media, using different data sources and open (big) data analytics, mobile broadband and cybersecurity (International Telecommunication Union, 2014). WEF points out that big data and analytics, cloud and mobile computing, open data initiatives and the explosive development of the Internet of Things are the new trends of ICT (World Economic Forum, 2014). According to the Waseda University, these global highlights as new trends in e-government development are as follows: cloud computing, social media, open government data, big data, business continuity planning in disaster management, digital inclusion in aging society, cybersecurity, one-stop service and interoperability, e-local government and smart cities (Waseda University, 2015). In the EU, new technologies such as social, mobile, big and open data, the Internet of Things, cloud computing and gamification are opening up more advanced practices and opportunities for better online services, thus reducing burdens and saving costs (European Commission, 2015). The most prominent trends identified by these organizations then are cloud computing, open (big) data, participation, collaboration, and social media.

\section{Cloud computing in e-government}

The aim of cloud computing is to provide computing, communication and storage resources based on a new service consumption and delivery model of computing infrastructure, storage capacity and applications as a service that are remotely (virtually) provided via Internet. It not only brings cost effectiveness but, more importantly, high levels of flexibility and scalability of services offered (Ali, Soar and Yong, 2014; Alshomrani and Qamar, 2013). Considering that the services provided in e-government are available through the Internet, cloud computing can be implemented to provide better services with the lowest economic cost using its benefits. Public sector institutions of the same type (e.g. hospitals, schools, police, and fire departments, etc.) or on the same level (e.g. regions, cities, etc.) have the same or very similar needs of ICT resources and data processing tools (Cellary and Strykowski, 2009). In such conditions, the cloud computing solution should be the first option to be chosen by governments.

According to the UN E-government Survey 2012 and the E-government Survey 2014 (United Nations, 2012; United Nations, 2014), it seems that increasingly complex public sector services in the future will be cloud based with service providers capable of addressing innovation and productivity upgrades without costly investments by the government. The opportunities offered by the digital development of recent years, whether through online services, open and big data, social media or mobile apps are expanding 
the way for e-government. However, as cloud services have grown, issues such as reliability of access, government access, data security and personal data protection, privacy and intellectual property protection have emerged as challenges to adoption (Mathew, 2013). It is very important for the public sector where are its data stored and how are they protected. In this context, a private (hybrid) cloud seems to be a better solution than the use of public clouds. There are concerns about data portability, vendor lock-in and interoperability, mostly related to public clouds (Asia Cloud Computing Association, 2014).

Janssen and Joha (2011) or Ali, Soar and Yong (2014) analyzed cloud computing and its applications in the context of e-government and described the possible benefits, disadvantages and challenges for e-government. Along similar lines, Hashemi, Monfaredi and Masdari (2013) studied the methods of using cloud computing in e-government to identify the challenges and benefits of this solution. They especially emphasized the analysis of huge volumes of data to detect any fraud or corruption, shared services, data integrity, stronger collaboration and knowledge exchange. Mathew (2013) discussed about Service-oriented architecture (SOA), challenges and benefits of using cloud computing by governments to solve all the difficulties faced by the stakeholders by providing various services. Vijaykumar (2011) then presented the applicability of each delivery model of cloud computing to various e-government development initiatives.

Mohammed and Ibrahim (2013) revisited the existing e-government development indices to show the main common indicators and then proposed a preliminary framework to refine indices' indicators according to the characteristics of the cloud computing. Also Mukherjee and Sahoo (2010) or Kurdi et al. (2011) designed a framework for assessing the readiness and deployment of e-government systems based on cloud computing. Kooshesh, Mollahasani and Barzegar (2013) proposed the integration of cloud computing in e-government systems to use the potential benefits and challenges of cloud computing for the users of e-services. They highlighted the rapid, easy and inexpensive scalability, increased flexibility, reduced costs, help to government to achieve better management and improve environmental conditions, etc. Also Alshomrani and Qamar (2013) claim that the use of cloud based e-government may help the governments provide best possible services to citizens and businesses, and reduce costs, too, as in cloud based e-government, they will not require to purchase and install the ICT on their own premises. Khan et al. (2011) concluded that by adopting cloud computing technologies, governments and public authorities can rather focus on their core business, which is serving the citizens, instead of thinking on ICT resource allocation and ICT maintenance tasks. The cloud computing model can help public sector institutions to provide highly reliable, innovative services quickly despite resource constraints, by applying innovations developed in the private sector (Zhang, 2014). All these results are in good agreement with other studies which have shown that there is a need for the use of cloud computing in the public sector.

\section{Open (big) data in e-government}

The rise of open government has seen a shift from the passive dissemination of information (mainly upon request) to proactive government dissemination of information particularly public data that can be massively analyzed and reused on a large scale. This opens the way for innovative uses of public data to generate both public (e.g. better 
services, greater transparency and accountability) and private (economic growth through the creation of new business lines) value (OECD, 2015). Open data offers new opportunities for integration of economic, social and environmental data, often in an easily accessible, localized and visualized format. Because of large amounts of data produced by the public sector, the open data model has evolved into an open (big) data model (Marton, Avital and Jensen, 2013; United Nations, 2012). While the big data are characterized as large in volume, gathered at high-speed, and may be also unstructured and come from many different sources, open data are about standards on how to make data machine-readable and hence linkable (Marton, Avital and Jensen, 2013). In 2012 and again in 2014, the United Nations issued big data and open government data for their EGovernment Survey reports, which summarized how governments utilized these data to better serve and protect their people (United Nations, 2012; United Nations, 2014). Also the ITU (International Telecommunication Union, 2014), the WEF (World Economic Forum, 2014) or the Waseda University (Waseda University, 2015) emphasizes that open government and open data should be implemented and shared with big data.

Consequently, many governments have started creating interoperability and open data frameworks which span boundaries between public sector institutions, citizens and businesses. Although there are many different sources of data, government data is particularly important because of its scale, scope, and status as the canonical source of information on a wide range of subjects (Van der Waal et al., 2014). A typical feature of European e-government initiatives is to provide distinct portals on government information and on online services for citizens (United Nations, 2014). Van der Waal et al. (2014) described the key functionalities of open data portals and presented a conceptual model to make data portals the backbone of a distributed global data warehouse for the information society on the Internet.

The literature on the reuse of open (big) data often circles around their potentials (Geiger and von Lucke, 2012) and the economic value of government data, while the literature on open government is in a higher grade directed towards government policy and centered on how the use of open data can contribute to generation of social value in collaborative settings (Jetzek, Avital and Bjørn-Andersen, 2013). As mentioned above, the interest in the concept of open (big) data has been around for many years, and driven in part by the pressure for increased public sector transparency and in part by the current enthusiasm for big data and data analytics, it continues to grow (Chen, Mao and Liu, 2014).

Although open (big) data provides many opportunities and capabilities for the public sector, its real impact will not be realized without carefully planned data management. Public sector institutions must have processes in place that clearly define the data to be shared with the users in which formats, at what time intervals and under which licenses, ensuring no restrictions on reuse of government information (United Nations, 2014). Tsiavos, Stefaneas and Karounos (2012) note that implementation of open (big) data policies is hindered by substantial barriers that may be attributed to different factors ranging from organizational and structural inefficiencies, monopolistic tendencies, complacency, conflicting or legacy legislation, lack of instruments of implementation and technical expertise or sheer lack of understanding of the utility of open (big) data by the decision-makers, particularly at the government level. They also emphasized the use 
of free/open source software and open architecture, which is the key ingredient for lowering of costs. Zuiderwijk and Janssen (2013) emphasized that due to complexity, lack of structure, uncertainty, dynamism, and the involvement of varying stakeholders in the open data process, it is necessary to apply coordination mechanisms such as standardization and interconnected processes. They identified the following to be coordination challenges: inappropriate regulatory environment, fragmentation of open (big) data, unclear boundaries of responsibilities, lack of feedback on and discussion of data use, lack of interconnected processes and lack of standardized and planned processes. Therefore, Solar, Concha and Meijueiro (2012) proposed an open data maturity model to assess the commitment and capabilities of public institutions in pursuing the principles and practices of open data, which has a hierarchical structure consists of domains, subdomains and critical variables. Hyland and Wood (2011) provide a six-step guidance model that contains the steps to identify, model, name, describe, convert, publish data, and the reverse activity to maintain them.

\section{Participation and collaboration trends in e-government}

Participation and collaboration are closely related to open (big) data and their transparency and accountability effects. They should help change the role of citizens and businesses from merely read-only users, to units that can benefit from open (big) data access and further opportunities offered by this access (Chu and Sun, 2013; Cowan, Alencar and Mcgarry, 2014; Krishnan, Teo and Lim, 2013). Several mechanisms have been developed with the objective of enhancing citizens' participation in the policy-making process. These mechanisms range from innovative public governance processes, such as participatory budgeting at the local level, to the use of social media for real-time interaction (OECD, 2015). As a result, the EPI by the UN is a sub-index in many other indices such as the NRI or the Waseda index (Máchová and Lněnička, 2015).

Social media can also play an important role in inspiring or enabling open government data usage, and in involving communities of practice, formed by people who engage in a process of collective learning related to open government data to sustain relevant initiatives and help create a network of actors. The use of social media to capture user feedback may help create a need for use, i.e. get data where people really need them (Ubaldi, 2013). It may also enable the development of collaborative and better-tailored channels of service delivery, two-way engagement and co-production of public services. However, while the use of social media platforms is widespread, there is a lack of effective measurement and benchmarking frameworks (OECD, 2015).

Also, in recent years, emerging green technologies have made significant technological advances and considerably decreased in cost, especially with the cloud becoming more prevalent. They may help governments go green by centralizing all the resources and improve the resource utilization, thereby reducing pollution and making the environment green (Mathew, 2013). Also the NRI separates environmental factors from ICT readiness, usage, and impact (World Economic Forum, 2014).

\section{Problem statement and the main objective}

A great number of frameworks and indices which measure and evaluate the egovernment development of the countries worldwide or in various regions of the world 
have been introduced since the beginning of the century (Máchová and Lněnička, 2015). There are also several researches devoted to study these issues. Bui, Sankaran and Sebastian (2003) proposed a framework to evaluate the e-government readiness of G7 countries and also selected Asian countries based on eight factors: digital infrastructure, macro economy, ability to invest, knowledgeable citizens, competitiveness, access to skilled workforce, culture, and cost of living and pricing. Gupta and Jana (2003) suggested that a flexible framework choose an appropriate strategy to measure the tangible and intangible benefits of e-government. West (2007) contributes to discussion of benchmarking by proposing an e-government index measuring the output or supply side of a government's web presence - the extent to which particular national websites provide a number of features and executable services. Rorissa, Demissie and Pardo (2011) introduced six frameworks for computing e-government indices and assessed the strengths and limitations of them. They concluded that benchmarking evaluations should be extended to include other means of access and delivery of e-government services, such as digital television or mobile technologies. Alghamdi, Goodwin and Rampersad (2011) proposed an integrated framework for assessing ICT readiness of egovernment organizations in developing countries, which emphasized organizational perspective for assessing ICT readiness that incorporates pertinent factors to an egovernment context.

Siskos, Askounis and Psarras (2014) evaluated and ranked selected EU Member States over their e-government progress based on a multi-criteria methodology consisting of eight criteria distinguished in four points of view: infrastructures, investments, eprocesses, and users' attitude. Their results were confirmed and extended by Kao (2015). However, with the current new trends in ICT such as cloud computing, open (big) data, participation and collaboration tools or social networks, there is a need to reframe and upgrade these indices, and to propose a new benchmarking framework. Following the previous part on the theoretical conceptualization of the selected e-government indices, cloud computing, open (big) data, participation, collaboration, social media, and looking at the related initiatives and development frameworks, it is possible to assume that their influence is growing.

Therefore, the main objective of this article is to incorporate these trends into a new egovernment benchmarking framework, represented by the e-government development index. To achieve this aim, the following tasks are defined: to analyze, compare and assess e-government development indices in past and present with respect to their methodologies; to examine the changes and trends defined by these indices; to identify the new trends in ICT and develop a framework for measurement of an e-government development; to select and propose relevant indicators; to weight indicators and groups of indicators; to normalize indicators to allow comparisons; to validate the new framework and assess the e-government development based on the new designed index; to focus on the results of the EU Member States and their comparison with existing indices. This will determine the level of agreement between the established indices and the newly proposed index.

This article is of significance in the domain of the e-government development and readiness as it extends the knowledge base that presently exists in this field. The new framework proposed measures specific impacts of cloud computing, open (big) data and 
related participation and collaboration tools, and uses key aspects of existing frameworks while introducing a number of additional criteria and measurement tools. The framework provides a more systematic approach to measure the role of these new trends in improving efficiency, innovation, transparency, participation and collaboration of governments, but it does not directly focus on the context-specific factors related to egovernment supply and demand such as the EUBR. Therefore, critical assessment of the proposed framework outlining the intended use and limitations will also be provided, before the final remarks and recommendations for future research. In contrast to standard published benchmarks, the whole approach should help decision makers, experts as well as businesses and public sector and by offering them an alternative evaluation solution.

The first part of this article explores the relevant literature on the e-government benchmarking frameworks and indices, and highlights assumptions and assertions around the use of the new trends in ICT in the e-government development. It identifies and compares the main benefits, challenges and trends. It is followed by the research methodology and the description of the new index's framework together with the weights of the proposed indicators. The last part then presents the results for the EU Member States based on the new designed e-government development index and compares them with the existing indices, using Kendall rank correlation coefficient.

\section{Research methodology and the description of the framework}

Based on the literature review and comparison of the indices described above, which aim to identify potential bottlenecks that could slow the e-government development and also serve to help identify the new trends in ICT, it is proposed that the new framework fulfill these requirements. The methodology used in this article is concept-centric, with the concepts determining the proposal of the benchmarking framework. For this purpose, the methods of decomposition and aggregation focusing on the principles of cloud computing, open (big) data, participation and collaboration in the public sector are used. The framework presented in this article is created in accordance with the steps identified in the Handbook on Constructing Composite Indicators by Nardo et al. (2008).

The proposal of this framework started with obtaining the necessary data sources focusing on the e-government development, benchmarking frameworks and related indices. It resulted in description of the progress of the e-government benchmarking frameworks' structure in the world. This part was presented in Máchová and Lněnička (2015). Then, the literature review on the new trends in ICT was conducted and the most recent and important trends were identified and compared. The basic framework was first introduced in Lněnička, Máchová and Komárková (2015), but based on the discussion and feedback received, it was further modified. The new proposed framework is represented by the e-government development index. As can be seen in the Table 2, this index is a composite measure of eight sub-indices which also consist of several indicators. Each one of these sets of sub-indices is in itself a composite measure that can be extracted and analyzed independently. It is weighted to reflect its importance to the new trends in ICT. Each individual indicator is also weighted to reflect its importance within each sub-index. Maximization is the benchmark for all of these indicators, credibility of which is mainly related to accuracy of the data and the methodology, based on which 
they are constructed (Nardo et al., 2008). Therefore, there are also data sources for the indicators used in the Table 2. The methodology of the construction of these indicators is briefly mentioned in the following chapter or it can be found in the related reports.

Table 2 Benchmarking framework of the e-government development index

\begin{tabular}{|c|c|c|c|}
\hline Sub-index & Indicator & Data source & $\begin{array}{c}\text { Weight } \\
{[\%]}\end{array}$ \\
\hline \multicolumn{3}{|c|}{ 1. Political environment and usage strategy index } & 10 \\
\hline & 1.1 Effectiveness of law-making bodies & WEF & 15 \\
\hline & 1.2 Laws relating to the ICT & WEF & 20 \\
\hline & 1.3 ICT use and government efficiency & WEF & 20 \\
\hline & 1.4 Government success in ICT promotion & WEF & 20 \\
\hline & 1.5 Cloud computing national framework or strategy & $\begin{array}{c}\text { survey of } \\
\text { experts }\end{array}$ & 25 \\
\hline \multicolumn{3}{|c|}{ 2. Privacy, freedom and intellectual property index } & 15 \\
\hline \multicolumn{3}{|c|}{ Privacy environment } & 35 \\
\hline & $\begin{array}{l}\text { 2.1 Member of Global Privacy Enforcement Network } \\
\text { (GPEN) }\end{array}$ & GPEN & 50 \\
\hline & 2.2 Privacy laws or regulations for cloud computing & $\begin{array}{l}\text { survey of } \\
\text { experts }\end{array}$ & 50 \\
\hline \multicolumn{3}{|c|}{ Freedom of information } & 35 \\
\hline & 2.3 Accessibility of digital content & WEF & 40 \\
\hline & 2.4 Democracy index & EIU & 30 \\
\hline & 2.5 Freedom of the press score & $\begin{array}{l}\text { Freedom } \\
\text { House }\end{array}$ & 30 \\
\hline & \multicolumn{2}{|l|}{ Intellectual property } & 30 \\
\hline & 2.6 Intellectual property protection & WEF & 55 \\
\hline & 2.7 International property rights index & $\begin{array}{l}\text { Property Rights } \\
\text { Alliance }\end{array}$ & 45 \\
\hline \multicolumn{3}{|c|}{ 3. ICT readiness, businesses and citizens' environment index } & 15 \\
\hline \multicolumn{3}{|c|}{ Citizens } & 55 \\
\hline & 3.1 Adult literacy rate & UNESCO & 15 \\
\hline & 3.2 Tertiary education gross enrolment rate & UNESCO & 15 \\
\hline & 3.3 Mean years of schooling & UNESCO & 20 \\
\hline & 3.4 Quality of educational system & WEF & 25 \\
\hline & $3.5 \mathrm{EPI}$ & UN & 25 \\
\hline \multicolumn{3}{|c|}{ Businesses } & 45 \\
\hline & 3.6 IT industry competitiveness index & BSA & 25 \\
\hline & 3.7 Global competitiveness index & WEF & 20 \\
\hline & 3.8 Availability of latest technologies & WEF & 30 \\
\hline & $\begin{array}{l}3.9 \text { Government procurement of advanced technology } \\
\text { products }\end{array}$ & WEF & 25 \\
\hline
\end{tabular}


4. Infrastructure and broadband quality index

4.1 National broadband plan

4.2 Fixed (wired) broadband subscriptions per 100 inhabit.

4.3 Wireless broadband subscriptions per 100 inhabitants

4.4 Mobile cellular telephone subscriptions per 100 inhabit.

4.5 Percentage of households with Internet access

4.6 Percentage of individuals using the Internet

4.7 International Internet bandwidth (bit/s) per Internet user experts

ITU

ITU

ITU

ITU

ITU 15

5. Government online services index 15

5.1 Impact of ICT on new services and products

WEF 20

5.2 E-service delivery stage 3 - transactional presence

UN 20

5.3 E-service delivery stage 4 - networked (connected) presence

UN

5.4 Use of virtual social networks

WEF

20

5.5 Unlicensed software installation rate

BSA

15

6. Data security index

6.1 Global risks index

6.2 Secure Internet servers per one million people

6.3 Electronic signature and identification laws or regulations

6.4 Laws or regulations containing general security requirements for digital data hosting 6.5 Laws or regulations that establish a framework for interoperability and portability of data

6.6 Effective legal protection from cybercrime

7. Open (big) data availability and impact index

$7.1 \mathrm{GODI}$

7.2 Open (big) data national framework or strategy

7.3 National open (government) data portal

7.4 Availability of data request form on the portal

7.5 Impact of open data on the economy

Maplecroft 20

World Bank 20

survey of

experts

survey of

experts

survey of

experts

W3F

OKF

experts

survey of

experts

survey of

experts

W3F

W3F

20

7.6 Impact of open data on transparency and accountability

8. Environmental and green policy index

8.1 Use of ICT to increase environmental awareness and behavioral change

W3F

8.2 Impact on environmental campaigns/action

W3F 20

8.3 Energy architecture performance index

WEF

25

8.4 Environmental performance index 
Compared to the e-government indices which were described above, the new proposed e-government development index differs in challenges of the cloud computing approach such as connectivity, policy and data security, which have higher weight in the proposed framework, and the indicators such as fixed telephone lines or fixed (wired) broadband subscriptions, which then have lower weight. Open (big) data are measured through their availability and impact. Participation and collaboration are represented by the EPI, which has the highest weight in its sub-index. Moreover, the indicator of PC users has been omitted in the framework because in addition to PCs, citizens may use smartphones, tablets and notebooks to connect with government and make transactions. Besides that, there are also nine own indicators which were received from a survey of experts' opinions.

Mathematically, the new index is a weighted average of eight normalized sub-indices on eight most important dimensions identified in the e-government development. The data for the evaluation and comparison were gathered from publicly available data sources and international reports.

\section{Political environment and usage strategy sub-index}

The success of a country in leveraging ICT depends in part on the quality of the overall operating environment. This sub-index therefore assesses the extent to which a country's market conditions and regulatory framework support innovation and ICT development (World Economic Forum, 2014).

This first sub-index deals with the legal framework and harmonization of international rules. Governments should work effectively to develop standards, while also working to minimize conflicting legal obligations on the cloud computing environment. The subindex examines the friendliness of a market and regulatory framework of a country in supporting high levels of ICT uptake. A supportive environment is necessary to maximize the potential impacts of ICT in boosting competitiveness and well-being. It takes into account general features of the regulatory environment (including laws relating to ICT and the efficiency of the law-making process), as well as more ICT specific dimensions such as ICT use and government efficiency and government success in ICT promotion. The existence of the cloud computing national framework or strategy is the most important indicator.

\section{Privacy, freedom and intellectual property sub-index}

The second sub-index covers the area of ensuring privacy and protecting intellectual property. The success of cloud computing depends on users' faith that their data will not be used or disclosed in unexpected ways. At the same time, providers must be free to move their data through the cloud in the most efficient way. In order to promote continued implementation of best practices, intellectual property laws have to provide legal framework for the cloud computing environment as well as open (big) data.

This sub-index consists of three parts: privacy environment, freedom of information and intellectual property. For the freedom of information three indicators are chosen, of which accessibility of digital content is the most important. Democracy index and Freedom of the press score represent the area to ensure promoting the benefits of cloud computing and open (big) data. Freedom of the press score by Freedom House ranges 
from 0 to 100, where 0-30 means free, 31-60 means partly free and 61-100 means not free. Thus, for the purpose of the proposed index, the scale was reversed. It also takes into account general features of the regulatory environment including the protection afforded to intellectual property rights through the intellectual property protection score and the international property rights index.

\section{ICT readiness, businesses and citizens' environment sub-index}

This sub-index is focused on the two groups of public services users (citizens and businesses) and assesses ICT readiness and skills of these two groups. It includes five indicators for citizens, and four for businesses. It measures the degree to which a society is prepared to participate in the digital economy, make effective use of modern ICT and digital content in order to build a competitive information society. The citizens' part of the sub-index examines the ability of a society to make effective use of ICT thanks to the existence of basic educational skills captured by the quality of the educational system, the level of adult literacy, and the rate of tertiary education enrolment. The EPI, which evaluates the participation and citizens' feedback on national initiatives, policies and online services, has the highest weight. The second group of indicators deals with competitiveness and availability of the latest technologies for businesses. It also measures presence of conditions that allow innovation to spread by including indicators of demand conditions for the government procurement of advanced technology products.

\section{Infrastructure and broadband quality sub-index}

The infrastructure and broadband quality index measures the quality of the ICT infrastructure and other factors supporting the uptake of ICT for the e-government services. Based on the new trends in ICT, especially at the time when the selected services are moved to cloud computing, they require robust, reliable and cost-effective broadband access, which stimulates citizens to use such services and encourages deployment of new services. This can be achieved through the policies that promote universal access to broadband and should stimulate the market, expand services and bring down prices.

It is based on comparative statistics on a range of important ICT indicators, including the presence of a national broadband plan, international internet bandwidth, and also includes statistics on the number of subscribers for various services. It reflects the importance of wireless and especially mobile broadband. On the other hand, fixed broadband uptake is growing more slowly and has lower weight in the proposed framework. Monitoring consumer uptake is important for the development and delivery of online public services. Thus, it is represented by the percentage of households with access to the Internet and the percentage of individuals using the Internet.

\section{Government online services sub-index}

Maturity of online public services is an important indicator to deliver these services to their users. The most recent trends show that some countries have shifted to useroriented strategies, and developed one-stop service portals. The third and the fourth stages of the UN's four stage online service model are used in this sub-index, because they are closely connected to cloud computing delivery and service models. This subindex provides insights into how important it is for governments to carry out ICT policies for competitiveness and to increase the well-being of their citizens and leverage the 
number of government services they provide online. This sub-index also measures the impact of ICT on new services and products, the use of virtual social networks as an indicator to implement multichannel platforms, portals and online services, and unlicensed software installation rate. The last indicator ranges from 0 to 100 as unlicensed software units as a percentage of total software units installed, therefore, the scale had to be reversed.

\section{Data security sub-index}

Data security sub-index examines promotion of security and data portability. It looks at whether security indicators and the ongoing testing of security measures are the subject of regulations. Users must be assured that cloud computing providers understand and properly manage the risks inherent in storing data and running applications in the cloud. The smooth flow of data around the world and between different cloud providers also requires efforts to promote openness, portability and interoperability. The same applies to open (big) data and various participation and collaboration tools.

Security of the data and data centers is covered by the global risks index and secure Internet servers per one million people. However, some of the indicators had to be eliminated or skipped, mostly because of the central directive of the EU, which is already implemented in the all EU Member States, e.g. multilateral international copyright treaties, or the unavailability/access to the selected report's raw data and coverage of these types of data. Freedom House also publishes the Freedom on the Net index, however, it only covers 60 countries worldwide (seven Member States of the EU). The Data Centre Risk Index by Cushman and Wakefield should be another suitable index, however, it covers only 30 countries (ten Member States of the EU). The other indicators used in this sub-index deal with the legal framework and environment such as effective legal protection from cybercrime, existence of electronic signature regulations, regulations containing general security requirements for digital data hosting and regulations that establish a framework for interoperability and portability of data. The last two indicators are closely related to cloud computing and their methodology is similar to the one proposed by the BSA index.

\section{Open (big) data availability and impact sub-index}

The seventh sub-index evaluates the score based on the GODI by the OKF, the existence of the dedicated open (big) data national framework or strategy, the national open (government) data portal and the availability of data request form on this portal. Some countries do not have any open data portal, only a statistical office portal. The last two indicators measure the impact of open data on the economy, and also how these data impact transparency and accountability.

\section{Environmental and green policy index}

The benefits of ICT and cloud computing such as scalability and flexibility (data loads vary, peak times etc.) eliminate costs and make the cloud servers more eco-friendly. The last sub-index may help governments go green. It describes the potential environmental benefits and the energy efficiency that cloud computing services delivered over the Internet can offer governments and society. This sub-index consists of the energy architecture performance index and the environmental performance index. It also evaluates 
the use of ICT to increase environmental awareness and behavioral change and the impact on environmental campaigns/action.

Validation of the proposed framework on the European Union level

Table 3 Data for the indicators proposed by the authors

\begin{tabular}{|c|c|c|c|c|c|c|c|c|c|}
\hline $\begin{array}{c}\text { Member State I } \\
\text { Indicator's number }\end{array}$ & 1.5 & 2.2 & 4.1 & 6.3 & 6.4 & 6.5 & 7.2 & 7.3 & 7.4 \\
\hline Austria & 4.6 & 2.8 & 5.0 & 5.0 & 2.8 & 2.0 & 4.4 & 5.0 & 4.2 \\
\hline Belgium & 2.4 & 1.2 & 5.0 & 5.0 & 1.2 & 1.0 & 4.6 & 4.8 & 3.8 \\
\hline Bulgaria & 1.2 & 1.0 & 5.0 & 5.0 & 1.0 & 1.0 & 2.2 & 5.0 & 4.8 \\
\hline Croatia & 1.2 & 1.0 & 5.0 & 4.6 & 1.0 & 1.0 & 3.8 & 5.0 & 2.6 \\
\hline Cyprus & 1.8 & 1.2 & 4.6 & 4.8 & 1.4 & 1.0 & 3.6 & 4.6 & 2.0 \\
\hline Czech Republic & 3.4 & 1.2 & 5.0 & 5.0 & 1.2 & 1.0 & 1.8 & 2.2 & 1.4 \\
\hline Denmark & 5.0 & 4.4 & 5.0 & 5.0 & 5.0 & 3.4 & 4.8 & 4.8 & 4.0 \\
\hline Estonia & 3.2 & 2.4 & 5.0 & 5.0 & 3.2 & 2.0 & 1.8 & 4.6 & 2.2 \\
\hline Finland & 3.4 & 3.0 & 5.0 & 5.0 & 3.0 & 1.8 & 4.0 & 5.0 & 3.2 \\
\hline France & 4.6 & 3.4 & 5.0 & 4.8 & 3.4 & 1.4 & 4.8 & 5.0 & 2.8 \\
\hline Germany & 4.6 & 3.6 & 5.0 & 5.0 & 3.4 & 2.4 & 4.8 & 5.0 & 2.0 \\
\hline Greece & 2.2 & 1.2 & 4.0 & 5.0 & 1.2 & 1.0 & 2.0 & 4.2 & 1.4 \\
\hline Hungary & 2.2 & 1.4 & 4.8 & 5.0 & 1.0 & 1.0 & 1.2 & 4.2 & 1.4 \\
\hline Ireland & 5.0 & 3.2 & 5.0 & 5.0 & 5.0 & 3.6 & 2.8 & 5.0 & 5.0 \\
\hline Italy & 3.4 & 2.8 & 5.0 & 4.8 & 1.8 & 1.2 & 4.2 & 5.0 & 4.8 \\
\hline Latvia & 1.4 & 1.0 & 4.8 & 5.0 & 1.0 & 3.4 & 2.2 & 4.4 & 1.2 \\
\hline Lithuania & 2.0 & 2.0 & 4.0 & 5.0 & 2.0 & 1.0 & 1.6 & 2.8 & 3.2 \\
\hline Luxembourg & 3.0 & 2.0 & 5.0 & 4.8 & 2.0 & 2.0 & 2.0 & 4.8 & 3.4 \\
\hline Malta & 4.4 & 3.6 & 3.8 & 5.0 & 4.2 & 2.6 & 2.2 & 4.6 & 1.4 \\
\hline Netherlands & 4.0 & 3.0 & 5.0 & 5.0 & 3.6 & 3.2 & 3.4 & 5.0 & 5.0 \\
\hline Poland & 2.6 & 1.2 & 4.8 & 5.0 & 1.6 & 1.0 & 4.0 & 4.8 & 3.0 \\
\hline Portugal & 3.8 & 2.8 & 5.0 & 4.8 & 3.0 & 1.4 & 2.6 & 4.8 & 4.6 \\
\hline Romania & 3.2 & 2.2 & 5.0 & 4.6 & 2.4 & 1.2 & 1.4 & 4.6 & 1.2 \\
\hline Slovakia & 2.0 & 1.2 & 5.0 & 5.0 & 1.2 & 1.0 & 2.2 & 4.6 & 1.2 \\
\hline Slovenia & 2.8 & 2.2 & 4.8 & 4.6 & 2.6 & 1.6 & 1.4 & 2.8 & 1.0 \\
\hline Spain & 3.0 & 2.0 & 4.8 & 4.4 & 2.0 & 1.2 & 3.2 & 5.0 & 5.0 \\
\hline Sweden & 4.0 & 3.6 & 5.0 & 5.0 & 3.2 & 2.8 & 4.2 & 4.6 & 2.4 \\
\hline United Kingdom & 5.0 & 4.0 & 5.0 & 5.0 & 5.0 & 4.0 & 5.0 & 5.0 & 4.0 \\
\hline
\end{tabular}


Table 3 shows the results for the newly proposed indicators to obtain all the data for a new e-government development index calculation. Each indicator was converted to a question and evaluated on a five point Likert scale to measure agreement or disagreement with such a statement $(1=$ Strongly Disagree, $2=$ Disagree, $3=$ Neutral, $4=$ Agree, 5 = Strongly Agree). Each question was evaluated by five experts focusing on the e-government development and the final value is an arithmetic mean of their answers. Number of selected indicator can be seen from the Table 2 .

Data used in the calculation of the e-government development index represent the most recent or/and best data available at the time when they were collected. It is possible that the data were updated or revised subsequently. These are mostly from 2014 and 2015, only indicators 3.2, 3.3 and 3.6 come from 2012, 2010 and 2011, respectively. The calculation of this new index is similar to methodology of the Waseda index (weighted average of the scores), the NRI (successive aggregations of scores), and the EGDI (normalized scale from zero to one). More information about these methodologies can be found in Waseda University (2015), World Economic Forum (2014) and United Nations (2014).

First, it is important for the indicators selected for the construction of the e-government development index that they transform the values to the same unit of measurement, since some of them are expressed as a percentage of the population or households, where the maximum value is 100 , while other indicators (although also expressed as a percentage) can have values exceeding 100 (mobile cellular telephone subscriptions or international Internet bandwidth, for example). Prior to the normalization of the eight sub-indices, the Z-score standardization procedure was implemented for each indicator (variable) to ensure that the overall e-government development index is equally decided by these sub-indices. In the absence of the Z-score standardization treatment, the index would mainly depend on the sub-index with the greatest dispersion. Z-score was calculated as illustrated in the equation (1):

$$
\text { standardized }\left(\mathrm{X}_{\mathrm{i}}\right)=\frac{\mathrm{X}_{\mathrm{i}}-\overline{\mathrm{X}_{\mathrm{s}}}}{\sigma_{\mathrm{X}, \mathrm{S}}}
$$

where $\overline{X_{S}}$ is the average of all the values for variable $X$ and $\sigma_{X, S}$ is the sample standard deviation of all the values for variable $X$. Then the weighted average for each sub-index and its variables was calculated (see weights in the Table 2). This value was then normalized by scaling between zero and one for each sub-index. The normalized value of $X_{i}$ for the sub-index $X$ was calculated as illustrated in the equation (2):

$$
\operatorname{normalized}\left(\mathrm{X}_{\mathrm{i}}\right)=\frac{\mathrm{X}_{\mathrm{i}}-\mathrm{X}_{\min }}{\mathrm{X}_{\max }-\mathrm{X}_{\min }}
$$

where $X_{\min }$ is the minimum standardized value for the sub-index $X$ and $X_{\max }$ is the maximum standardized value for the sub-index $X$. The overall e-government development index was derived by taking the weighted average of the eight sub-indices. The final form of the construction of the new index is as follows (3):

$$
\text { new index } \mathrm{x}_{\text {country } Y}=\frac{1}{10} X_{1}+\frac{3}{20} X_{2}+\frac{3}{20} X_{3}+\frac{3}{20} X_{4}+\frac{3}{20} X_{5}+\frac{1}{10} X_{6}+\frac{3}{20} X_{7}+\frac{1}{20} X_{8}
$$


where country ${ }_{\mathrm{Y}}$ is the EU Member State and $\mathrm{X}_{\mathrm{i}}, \mathrm{i}=1,2 \ldots 8$ is the sub-index.

The results are presented in the Table 4 as a set of normalized values on a scale from zero to one, one corresponding to the highest rated Member State and zero to the lowest rated Member State. The best value for each sub-index is in bold.

Table 4 E-government development index for the EU Member States in 2015

\begin{tabular}{|c|c|c|c|c|c|c|c|c|c|c|}
\hline $\begin{array}{c}\text { Member State I } \\
\text { No. of sub-index }\end{array}$ & 1. & 2. & 3. & 4. & 5. & 6. & 7. & 8. & $\begin{array}{c}\text { New } \\
\text { index }\end{array}$ & Ranl \\
\hline Austria & 0.703 & 0.584 & 0.667 & 0.575 & 0.618 & 0.692 & 0.742 & 0.880 & 0.662 & 8. \\
\hline Belgium & 0.1 & ודט & 0.696 & 0.495 & 0.628 & 0.549 & 0.732 & 0.712 & 0.615 & 12. \\
\hline Bulgaria & .136 & 0.258 & 0.314 & 0.324 & 0.171 & 0.154 & 0.480 & 69 & 0.270 & 7. \\
\hline Croatia & 0.163 & 0.141 & 0.315 & 0.369 & 0.297 & 0.058 & 0.481 & 0.247 & 0.275 & 26. \\
\hline Cyprus & 0.364 & 0.291 & 0.406 & 0.218 & 0.421 & 0.153 & 0.379 & 0.133 & 0.316 & 24. \\
\hline $\mathrm{Cze}$ & 318 & 0.516 & 0.435 & 0.421 & 0.396 & 19 & .261 & 55 & 0.421 & 17. \\
\hline Denmark & 0.742 & 0.691 & 0.671 & 0.736 & 0.542 & 0.909 & 0.866 & 0.892 & 0.736 & 4. \\
\hline Estonia & 0.812 & 0.665 & 0.696 & 0.600 & 0.707 & 0.663 & 0.405 & 0.670 & 0.642 & 10. \\
\hline Finland & 0.735 & 0.726 & 0.850 & 0.785 & 0.779 & 0.747 & 0.802 & 0.786 & 0.779 & 3. \\
\hline France & 0.655 & 0.711 & 0.709 & 0.508 & 0.739 & 0.588 & 0.818 & 96 & 0.687 & 1. \\
\hline Germany & 0.719 & 0.801 & 0.800 & 0.542 & 0.547 & 0.746 & 0.691 & 0.822 & 0.695 & 6. \\
\hline 0000 & 0.146 & 0124 & 0.400 & 0169 & 4 & 0. & 0 & 5 & 77 & 5. \\
\hline Hungary & 0.010 & 0.422 & 0.441 & 0.343 & 0.324 & 0.447 & 0.364 & 00 & 0.395 & 20. \\
\hline Ireland & 0.724 & 0.735 & 0.716 & 0.467 & 0.624 & 0.798 & 0.547 & 0.700 & 0.651 & 9. \\
\hline Italy & 0.169 & 0.428 & 0.451 & 0.449 & 0.464 & 0.283 & 0.692 & 0.585 & 0.447 & 16. \\
\hline Latvia & 0.010 & 0.254 & 0.555 & 0.448 & 0.477 & 0.489 & $0.0<2$ & 0.261 & 0.402 & 19. \\
\hline Lithuania & 0.447 & 0.511 & 0.533 & 0.307 & 0.601 & 0.394 & 0.212 & 0.174 & 0.417 & 18. \\
\hline Luxembourg & 0.838 & 0.813 & 0.553 & 0.857 & 0.626 & 0.588 & 0.318 & 0.395 & 0.637 & 11. \\
\hline Malta & 0.760 & 0.716 & 0.408 & 0.343 & 0.403 & 0.474 & 0.346 & 0.129 & 0.462 & 15. \\
\hline Netherlands & 0.724 & 0.848 & 0.855 & 0.643 & 0.909 & 0.873 & 0.705 & 0.741 & 0.791 & 2. \\
\hline Poland & 0.233 & 0.386 & 0.406 & 0.394 & 0.222 & 0.530 & 0.509 & 0.559 & 0.392 & 21. \\
\hline Portugal & 0.681 & 0.466 & 0.498 & 0.309 & 0.537 & 0.523 & 0.534 & 0.690 & 0.507 & 14. \\
\hline Romania & 0.317 & 0.161 & 0.385 & 0.213 & 0.198 & 0.113 & 0.321 & 0.145 & 0.242 & 28. \\
\hline Slovakia & 0.181 & 0.273 & 0.407 & 0.412 & 0.352 & 0.373 & 0.304 & 0.327 & 0.334 & 23. \\
\hline Slovenia & 0. & 0.519 & 0.504 & 0.376 & 0.320 & 0.382 & 0.165 & 0.369 & 0.373 & 22. \\
\hline Spain & 0.432 & 0.497 & 0.523 & 0.385 & 0.625 & 0.396 & 0.666 & 0.693 & 0.522 & 13. \\
\hline Sweden & 0.765 & 0.717 & 0.756 & 0.707 & 0.728 & 0.773 & 0.650 & 0.892 & 0.732 & 5. \\
\hline United Kingdom & 0.814 & 0.843 & 0.745 & 0.650 & 0.888 & 0.876 & 0.963 & 0.800 & 0.822 & 1. \\
\hline
\end{tabular}

Source: Authors 
Figure 1 shows the values of the government development index for each EU Member State. There is also the mean value together with the highlighted EU Member States, which are above this line. Estonia is the only Member State which joined the EU after 2004 and it is in this group. As depicted in the Figure 2, each sub-index contributes differently to this weighted index. This shows that a country like Croatia is very strong in the open (big) data availability and impact, but very weak in data security.

Figure 1 E-government development index values for each EU Member State

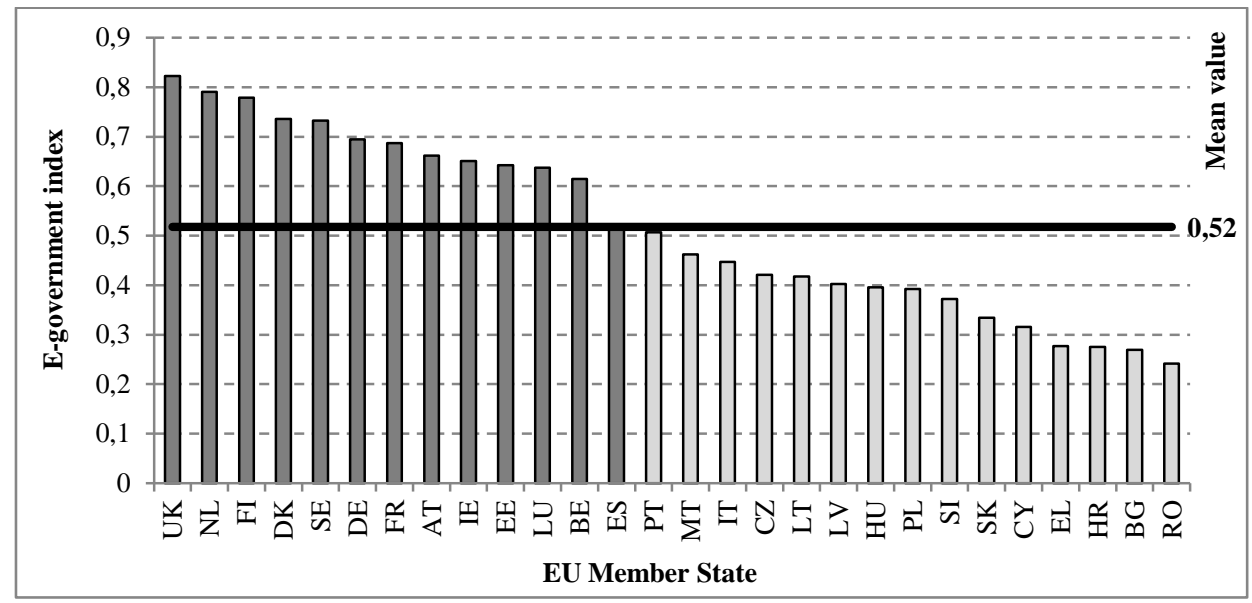

Source: Authors

Figure 2 Contribution of each sub-index to overall e-government development index

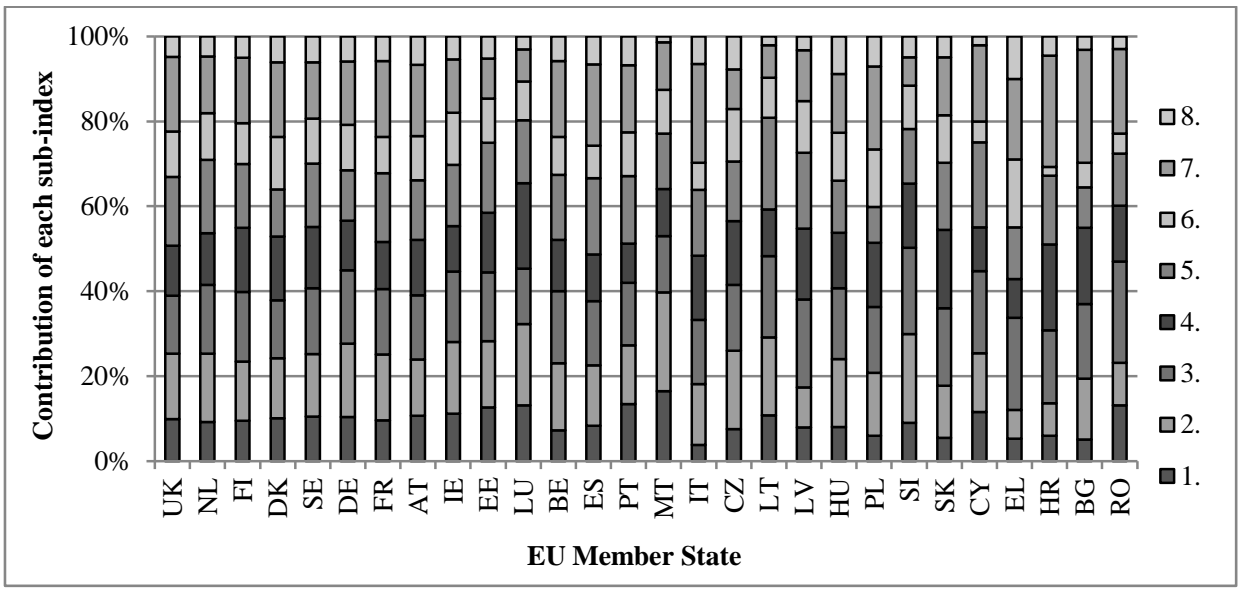

Source: Authors 
More detailed information about the best performing Member States can be seen on the spider graph in the Figure 3. The biggest differences between these countries are represented by the open (big) data availability and impact index, where the UK is on the top of the list, and the government online services index, where the Netherlands is on the top of the list. Political environment and usage strategy index and the ICT readiness, businesses and citizens' environment index are the most consistent sub-indices. These findings reveal that political, businesses and citizens environments are very similar in the EU Member States (mostly due to their policies, governmental structures and also implementation of the EU legislation in national law) and the main differences are caused by a different strategy to implement the new trends in ICT such as cloud computing, open (big) data, participation and collaboration tools, online services or data security solutions.

Figure 3 Top ten ranking of the e-government development index

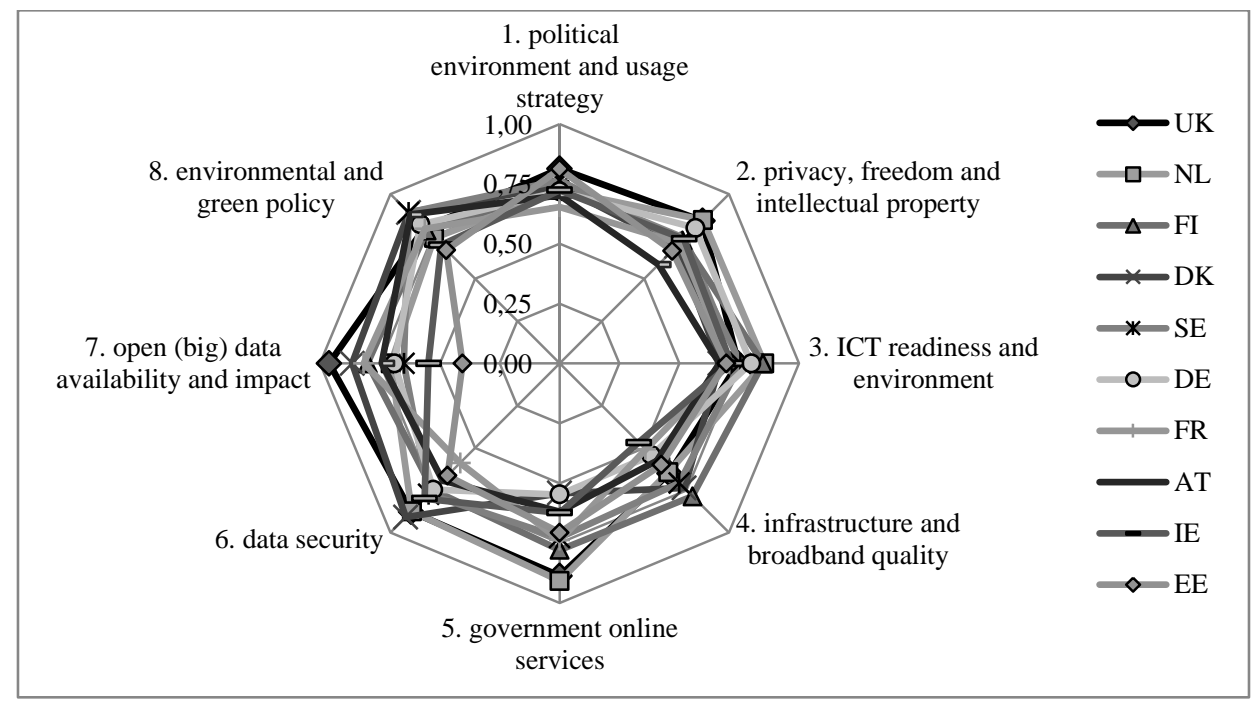

Source: Authors

In order to provide comparison to the results presented in the previous table, Table 5 presents the selected most recent e-government development indices for the EU Member States and especially the mean ranking for them. This ranking, together with the ranking presented in the Table 4, is also compared in the Figure 4, where the EU Member States are sorted by the ranking from the Table 5 (rank 2 in this figure). Rank 1 then represents the new e-government development index. United Kingdom, which has only the fourth place among the EU in the Table 5, is the Member State with the highest value of this index. It is because of the very good results in the area of open (big) data and data security solutions. In general, there are some interesting differences in the rankings between the EU Member States in the Table 4 and Table 5. The biggest difference can be found in the results of Croatia and Greece which both lost five places in the new index. On the other hand, the Czech Republic and Portugal have improved their 
positions compared to the results in the Table 5. Both have very good results in the area of the environmental and green policy. Slovakia also moved up three places, mostly because of the ICT readiness, businesses and citizens' environment.

Table 5 Comparison of the EU Member States based on the selected e-government indices

\begin{tabular}{|c|c|c|c|c|c|c|c|c|c|c|}
\hline \multirow{3}{*}{$\begin{array}{l}\text { Member State / } \\
\text { Index }\end{array}$} & \multicolumn{3}{|c|}{ EGDI 2014} & \multicolumn{3}{|c|}{ IDI 2014} & \multicolumn{3}{|c|}{ NRI 2015} & \multirow{3}{*}{$\begin{array}{c}\text { The mean } \\
\text { rank } \\
\text { among the } \\
\text { EU }\end{array}$} \\
\hline & \multirow[b]{2}{*}{ Value } & \multicolumn{2}{|c|}{ Ranking } & \multirow[b]{2}{*}{ Value } & \multicolumn{2}{|c|}{ Ranking } & \multirow[b]{2}{*}{ Value } & \multicolumn{2}{|c|}{ Ranking } & \\
\hline & & global & $\begin{array}{l}\text { among } \\
\text { the EU }\end{array}$ & & global & $\begin{array}{l}\text { among } \\
\text { the EU }\end{array}$ & & global & $\begin{array}{l}\text { among } \\
\text { the EU }\end{array}$ & \\
\hline Austria & 0.791 & 20. & 9. & 7.62 & 24. & 10. & 5.4 & 20. & 8. & 10. \\
\hline Belgium & 0.756 & 25. & 14. & 7.57 & 25. & 11. & 5.3 & 24. & 10. & 13. \\
\hline Bulgaria & 0.542 & 73. & 28. & 6.31 & 49. & 26. & 4.0 & 73. & 28. & 28. \\
\hline Croatia & 0.628 & 47. & 23. & 6.90 & 37. & 18. & 4.3 & 54. & 23. & 21. \\
\hline Cyprus & 0.596 & 58. & 26. & 6.11 & 51. & 27. & 4.7 & 36. & 18. & 25. \\
\hline Czech Republic & 0.607 & 53. & 25. & 6.72 & 41. & 21. & 4.5 & 43. & 20. & 23. \\
\hline Denmark & 0.816 & 16. & 8. & 8.86 & 1. & 1. & 5.5 & 15. & 7. & 5. \\
\hline Estonia & 0.818 & 15. & 7. & 7.68 & 21. & 9. & 5.3 & 22. & 9. & 9. \\
\hline Finland & 0.845 & 10. & 4. & 8.31 & 8. & 5. & 6.0 & 2. & 1. & 2. \\
\hline France & 0.894 & 4. & 1. & 7.87 & 18. & 8. & 5.2 & 26. & 12. & 6. \\
\hline Germany & 0.786 & 21. & 10. & 7.90 & 17. & 7. & 5.5 & 13. & 6. & 7. \\
\hline Greece & 0.712 & 34. & 17. & 6.85 & 39. & 19. & 4.1 & 66. & 27. & 20. \\
\hline Hungary & 0.664 & 39. & 19. & 6.52 & 46. & 25. & 4.3 & 53. & 22. & 22. \\
\hline Ireland & 0.781 & 22. & 11. & 7.57 & 26. & 12. & 5.2 & 25. & 11. & 11. \\
\hline Italy & 0.759 & 23. & 12. & 6.94 & 36. & 17. & 4.3 & 55. & 24. & 17. \\
\hline Latvia & 0.718 & 31. & 16. & 7.03 & 33. & 16. & 4.7 & 33. & 16. & 15. \\
\hline Lithuania & 0.727 & 29. & 15. & 6.74 & 40. & 20. & 4.9 & 31. & 15. & 16. \\
\hline Luxembourg & 0.759 & 24. & 13. & 8.26 & 10. & 6. & 5.6 & 9. & 5. & 8. \\
\hline Malta & 0.652 & 40. & 20. & 7.25 & 30. & 14. & 4.9 & 29. & 14. & 14. \\
\hline Netherlands & 0.890 & 5. & 2. & 8.38 & 7. & 4. & 5.8 & 4. & 3. & 1. \\
\hline Poland & 0.648 & 42. & 22. & 6.60 & 44. & 23. & 4.4 & 50. & 21. & 24. \\
\hline Portugal & 0.690 & 37. & 18. & 6.67 & 43. & 22. & 4.9 & 28. & 13. & 18. \\
\hline Romania & 0.563 & 64. & 27. & 5.83 & 58. & 28. & 4.2 & 63. & 26. & 27. \\
\hline Slovakia & 0.615 & 51. & 24. & 6.58 & 45. & 24. & 4.2 & 59. & 25. & 26. \\
\hline Slovenia & 0.651 & 41. & 21. & 7.13 & 31. & 15. & 4.6 & 37. & 19. & 19. \\
\hline Spain & 0.841 & 12. & 5. & 7.38 & 28. & 13. & 4.7 & 34. & 17. & 12. \\
\hline Sweden & 0.823 & 14. & 6. & 8.67 & 3. & 2. & 5.8 & 3. & 2. & 3. \\
\hline United Kingdom & 0.870 & 8. & 3. & 8.50 & 5. & 3. & 5.6 & 8. & 4. & 4. \\
\hline
\end{tabular}


Figure 4 Comparison of the two sets of rankings

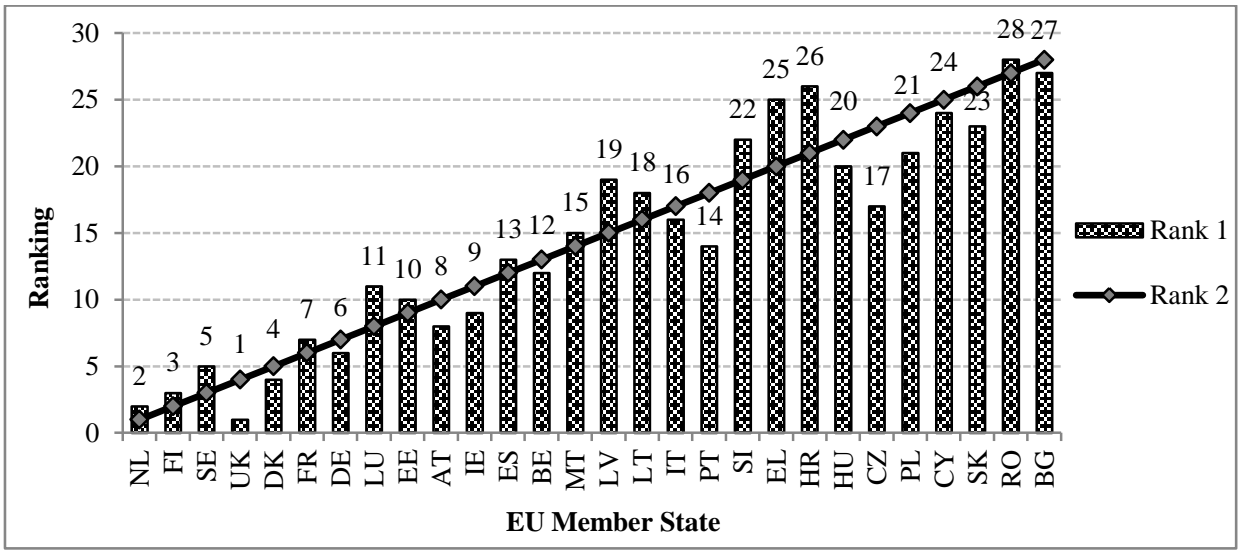

Source: Authors

According to Nardo et al. (2008), several correlation measures (measures of association) can be used to validate the conformity of the assessment (rank) methods for the newly proposed index and the existing indices, such as Pearson's correlation coefficient, Spearman's rank correlation coefficient or Kendall's rank correlation coefficient, Correlation ratio or Mutual information. Thus, Kendall's rank correlation coefficient is used because it measures the degree of correspondence between two rankings and the statistical significance of this association. It was calculated as illustrated in the equation (4):

$$
\tau=\frac{4 P}{n(n-1)}-1
$$

where $P$ is the sum of concordant pairs in the two rankings, and $n$ is the number of the EU Member States. More precisely, $P$ is the sum, over all the items, of items ranked after the given item by both rankings. Therefore, if the two rankings are equal, $\tau=1$; if they are completely opposite, $\tau=-1$. If the rankings are completely independent, $\tau=0$ (Nardo et al., 2008). In the case of the rank 1 and rank 2 from the Figure 4, the resulting value is $\tau=0.81$. For the new index (rank 1) and the EGDI it is $\tau=0.74$, the IDI ( $\tau=$ $0.75)$ and the NRI $(\tau=0.76)$. High values of this coefficient indicate that the newly proposed index ranks countries in terms of their e-government development very similarly to the currently used e-government indices.

Although it is difficult to create homogeneous groups of the EU Member States, a broad classification by geography shows that Northern and Western Europe countries depict much stronger results than Southern and Eastern Europe. In Central and Eastern Europe, for example, Estonia has values that are similar to those of some of the countries in Western Europe; in Southern Europe, Spain and Portugal outperform Greece. The results show that the approaches of cloud computing, the use of open (big) data and various participation and collaboration tools are still in early stages of implementation in most of the EU Member States, except for the UK, Netherlands, Finland or Denmark. However, the differences are yet not significant enough to clearly evaluate the im- 
portance, benefits and risks of cloud computing, open (big) data, participation and collaboration tools in the e-government development in the EU Member States.

While the proposed framework is based on the new trends in ICT received through the extensive literature review, the indicators comprising the framework and their weights are offered for debate and, consequently, may evolve over time. Another problem is that all the indicators used target only the e-government development on the national level. In practice, many services are the responsibility of lower levels of government. Also the benchmarking evaluations should focus more on the in-depth analysis of the political nature of the e-government development processes, and a deeper recognition of complex political and institutional environments and participation patterns, which affect the further implementation of the new trends in ICT. This approach is supported e.g. by Yildiz (2007) or Rorissa, Demissie and Pardo (2011). However, solving of this problem requires a more detailed research.

\section{Conclusion}

All EU Member States are assessed and ranked over their e-government development focusing on the new trends in ICT. A framework, methodology and new index are developed to capture and evaluate the development of the information society as it goes through its different stages, taking technology convergence and the emergence of new ICT into consideration. Kendall's rank correlation coefficient is used to validate the conformity of the rank methods for the newly proposed index and the existing indices. The results show that the newly proposed index ranks countries in terms of their egovernment development very similarly to the currently used e-government indices.

The most important results presented through the framework proposed are discussed in this article to show how a cloud computing solution and open (big) data can affect the egovernment development. The related issues such as legal framework, infrastructure and security are also emphasized. It is worth noting that deployment of e-government solutions in the form of cloud computing enables benefits from economies of scale. It also bears a social impact and enables advanced ICT solutions to be rapidly available to all public institutions, irrespective of locations or level of technical competencies. The issue of opening up data has increasingly to mature and be framed as a broader online service together with the various participation and collaboration tools.

The findings presented in this article may help government planners and decisionmakers devise better plans and come up with more quality decisions regarding egovernment and achieve better outcomes in the e-government development. The proposed new framework may also be expanded to include other countries in the world, too, while selected indicators may be changed or reweighted to measure the impact of new technologies on the e-government development. Finally, it may help broaden the existing literature on the e-government development. 


\section{References}

AL-KHOURI, A. M. (2011). An Innovative Approach for e-Government Transformation. International Journal of Managing Value and Supply Chains, 2(1), 22-43. ISSN 0976-979X.

ALGHAMDI, I. A.; GOODWIN, R.; RAMPERSAD, G. (2011). E-Government Readiness Assessment for Government Organizations in Developing Countries. Computer and Information Science, 4(3), 3-17. ISSN 1913-8997.

ALI, O.; SOAR, J.; YONG, J. (2014). Impact of Cloud Computing Technology on EGovernment. In: Proceedings of the 20th International Conference on Information and Software Technologies (ICIST 2014), Springer International Publishing, pp. 272-290. ISBN 978-3-319-11958-8.

ALSHOMRANI, S.; QAMAR, S. (2013). Cloud Based E-Government: Benefits and Challenges. International Journal of Multidisciplinary Sciences and Engineering, 4(6), 15-19. ISSN 2045-7057.

ASIA CLOUD COMPUTING ASSOCIATION. (2014). Cloud Readiness Index 2014. Singapore: Asia Cloud Computing Association. [Online] Available at: http://www.asiacloudcomputing.org/images/research/ACCA_CRI2014_ForWeb.pdf

BANNISTER, F. (2007). The curse of the benchmark: an assessment of the validity and value of e-government comparisons. International Review of Administrative Sciences, 73(2), 171-188. ISSN 1461-7226.

BUI, T. X.; SANKARAN, S.; SEBASTIAN, I. M. (2003). A framework for measuring national e-readiness. International Journal of Electronic Business, 1(1), 3-22. ISSN 1741-5063. DOI: 10.1504/IJEB.2003.002162

CELLARY, W.; STRYKOWSKI, S. (2009). E-Government Based on Cloud Computing and Service-Oriented Architecture. In: Proceedings of the 3rd International Conference on Theory and Practice of Electronic Governance (ICEGOV 2009), ACM, pp. 5-10. ISBN 978-1-60558-663-2.

CHEN, M.; MAO, S.; LIU, Y. (2014). Big Data: A Survey. Mobile Networks and Applications, 19(2), 171-209. ISSN 1572-8153. DOI: $\underline{\text { 10.1007/s11036-013-0489-0 }}$

CHU, P.; SUN Y. (2013). A Prospective Survey on Future e-Governance Research Directions. In: Proceedings of the 13th European Conference on eGovernment (ECEG 2013), Academic Conferences and Publishing International Limited, Reading, pp. 127134. ISBN 978-1-909507-25-8.

CODAGNONE, C.; UNDHEIM, T. A. (2008). Benchmarking e-government: Tools, theory, and practice. European Journal of ePractice, 4, 4-18. ISSN 1988-625X.

COWAN, D.; ALENCAR, P.; MCGARRY, F. (2014). Perspectives on Open Data: Issues and Opportunties. In: Proceedings of the 2014 IEEE International Conference on Software Science, Technology and Engineering, IEEE, pp. 24-33. ISBN 978-0-76955188-3. 
DAWES, S. S.; PARDO, T. A.; CRESSWELL, A. M. (2004). Designing Electronic Government Information Access Programs: A Holistic Approach. Government Information Quarterly, 21(1), 3-23. ISSN 0740-624X. DOI: 10.1016/j.giq.2003.11.001

EUROPEAN COMMISSION. (2015). Future-proofing eGovernment for a Digital Single Market. Luxembourg: Publications Office of the European Union. ISBN 978-92-7948427-8.

GEIGER, C. P.; VON LUCKE, J. (2012). Open Government and (Linked) (Open) (Government) (Data). eJournal of eDemocracy \& Open Government, 4(2), 265-278. ISSN 2075-9517.

GRÖNLUND, Å. (2011). Connecting eGovernment to Real Government - The Failure of the UN eParticipation Index. In: Proceedings of the 10th IFIP WG 8.5 International Conference (EGOV 2011), Springer, Berlin, pp. 26-37. ISBN 978-3-642-22877-3.

GUPTA, M. P.; JANA, D. (2003). E-government evaluation: A framework and case study. Government Information Quarterly, 20(4), 365-387. ISSN 0740-624X. DOI: 10.1016/j.giq.2003.08.002

HANSEN, H. S.; HVINGEL, L.; SCHRØDER, L. (2013). Open Government Data - A Key Element in the Digital Society. In: Technology-Enabled Innovation for Democracy, Government and Governance, Springer, Berlin, pp. 167-180. ISBN 978-3-642-40160-2.

HASHEMI, S.; MONFAREDI, K.; MASDARI, M. (2013). Using Cloud Computing for E-Government: Challenges and Benefits. International Journal of Computer, Information, Systems and Control Engineering, 7(9), 596-603. ISSN 1307-6892.

HYLAND, B.; WOOD, D. (2011). The Joy of Data-A Cookbook for Publishing Linked Government Data on the Web. In: Linking Government Data, Springer, New York, pp. 3-26. ISBN 978-1-4614-1767-5.

INTERNATIONAL TELECOMMUNICATION UNION. (2014). Measuring the Information Society Report 2014. Geneva: Telecommunication Development Bureau. ISBN 978-92-61-15291-8.

JANSSEN, M.; JOHA, A. (2011). Challenges for Adopting Cloud-based Software as a Service (SaaS) in the Public Sector. In: Proceedings of the ECIS 2011 European conference on Information Systems (ECIS 2011), Helsinki, Finland, Paper 80.

JETZEK, T.; AVITAL, M.; BJØRN-ANDERSEN, N. (2013). Generating Value from Open Government Data. In: Proceedings of 34th International Conference on Information Systems (ICIS 2013), Bepress, Berkeley, pp. 1-20. ISBN 978-0-615-93383-2.

KAO, C. (2015). Evaluation and improvement of e-government: The case of European countries. In: Proceedings of the Second International Conference on eDemocracy \& eGovernment (ICEDEG 2015), IEEE, pp. 104-107. ISBN 978-3-907589-10-6.

KHAN, F.; ZHANG, B.; KHAN, S.; CHEN, S. (2011). Technological leap frogging egovernment through cloud computing. In: Proceedings of the 4th IEEE International Conference on Broadband Network and Multimedia Technology (IC-BNMT 2011), IEEE, pp. 201-206. ISBN 978-1-61284-157-1. 
KOOSHESH, R.; MOLLAHASANI, M.; BARZEGAR, H. R. (2013). Implement EGovernment Based Approach on Cloud computing. Journal of Basic and Applied Scientific Research, 3(11), 488-493. ISSN 2090-424X.

KRISHNAN, S.; TEO T.; LIM, J. (2013). E-Participation and E-Government Maturity: A Global Perspective. In: Grand Successes and Failures in IT: Public and Private Sectors, Springer, Berlin, pp. 420-435. ISBN 978-3-642-38862-0.

KURDI, R.; TALEB-BENDIAB, A.; RANDLES, M.; TAYLOR, M. (2011). EGovernment Information Systems and Cloud Computing (Readiness and Analysis). In: Proceedings of the 2011 International Conference on Developments in eSystems Engineering (DeSE 2011), IEEE, pp. 404-409. ISBN 978-1-4577-2186-1.

LNĚNIČKA, M.; MÁCHOVÁ, R.; KOMÁRKOVÁ, J. (2015). Cloud E-Government Index as a New Benchmarking Framework for the Public Sector. In: Proceedings of the 19th International Conference Current Trends in Public Sector Research, Masaryk University, Brno, pp. 29-37. ISBN 978-80-210-7532-0.

MÁCHOVÁ, R.; LNĚNIČKA, M. (2015). Vývoj struktury hodnotících rámců pro měření rozvoje e-governmentu ve světě. Acta academica karviniensia, 15(1), 105-118. ISSN 1212-415X.

MARTON, A.; AVITAL, M.; JENSEN, T. B. (2013). Reframing Open (big) data. In: Proceedings of the 21st European Conference on Information Systems, Utrecht, The Netherlands, pp. 1-12.

MATHEW, S. (2013). Implementation of Cloud Computing In E-Governance - A Green Revolution. International Journal of Innovative Technology and Research, 1(4), 341-345. ISSN 2320-5547.

MOHAMMED, F.; IBRAHIM, O. (2013). Refining E-government Readiness Index by Cloud Computing. Jurnal Teknologi, 65(1), 23-34. ISSN 0127-9696. DOI: 10.11113/jt.v65.1759

MUKHERJEE, K.; SAHOO, G. (2010). Cloud Computing: Future Framework for eGovernance. International Journal of Computer Applications, 7(7), 31-34. ISSN 09758887. DOI: $10.5120 / 1262-1613$

NARDO, M. et al. (2008). Handbook on Constructing Composite Indicators: Methodology and user Guide. Paris: OECD Publishing. ISBN 978-92-64-04345-9.

OECD. (2015). Government at a Glance 2015. Paris: OECD Publishing. ISBN 978-9264-23346-1.

RORISSA, A.; DEMISSIE, D.; PARDO, T. (2011). Benchmarking e-Government: A comparison of frameworks for computing e-Government index and ranking. Government Information Quarterly, 28(3), 354-362. ISSN 0740-624X. DOI: 10.1016/j.giq.2010.09.006

SISKOS, E.; ASKOUNIS, D.; PSARRAS, J. (2014). Multicriteria decision support for global e-government evaluation. Omega, 46, 51-63. ISSN 0305-0483. DOI: 10.1016/j.omega.2014.02.001 
SISKOS, E.; MALAFEKAS, M.; ASKOUNIS, D.; PSARRAS, J. (2013). E-government Benchmarking in European Union: A Multicriteria Extreme Ranking Approach. In: Proceedings of the 12th IFIP WG 6.11 Conference on e-Business, e-Services, and eSociety (I3E 2013), Springer, Berlin, pp. 338-348. ISBN 978-3-642-37437-1.

SOLAR, M.; CONCHA, G.; MEIJUEIRO, L. (2012). A Model to Assess Open Government Data in Public Agencies. In: Proceedings of the 11th IFIP WG 8.5 International Conference (EGOV 2012), Springer, Heidelberg, pp. 210-221. ISBN 978-3-64233489-4.

TSIAVOS, P.; STEFANEAS, P.; KAROUNOS, T. (2012). Financial Crisis and The Promised Land of Open Data. In: Proceedings of the conference IPP2012: Big Data, Big Challenges?, Oxford Internet Institute, Oxford, United Kingdom, pp. 1-21.

UBALDI, B. (2013). Open Government Data: Towards Empirical Analysis of Open Government Data Initiatives. OECD Working Papers on Public Governance, 22, 1-61. ISSN 1993-4351.

UNITED NATIONS. (2012). United Nations E-government Survey 2012: EGovernment for the People. New York: UN Publishing Section. ISBN 978-92-1123190-8.

UNITED NATIONS. (2014). United Nations e-Government Survey 2014: EGovernment for the Future We Want. New York: UN Publishing Section. ISBN 978-921-123198-4.

VAN DER WAAL, S. et al. (2014). Lifting Open Data Portals to the Data Web. In: Linked Open Data - Creating Knowledge Out of Interlinked Data. Springer International Publishing, pp. 175-195. ISBN 978-3-319-09846-3.

VIJAYKUMAR, N. (2011). Role of ICT in e-Governance: Impact of Cloud Computing in Driving New Initiatives. SETLabs Briefings, 9(2), 43-52.

WASEDA UNIVERSITY. (2015). 2015 Waseda - IAC International E-government Ranking Survey. Tokyo: Waseda University. [Online] Available at: http://www.egov.waseda.ac.jp/pdf/2015_Waseda_IAC_E-Government_Press_Release.pdf

WEST, D. M. (2007). Digital Government: Technology and Public Sector Performance. Princeton, NJ: Princeton University Press. ISBN 9781400835768.

WORLD ECONOMIC FORUM. (2014). The Global Information Technology Report 2014: Rewards and Risks of Big Data. Geneva: SROKundig. ISBN 978-92-95044-63-0.

YILDIZ, M. (2007). E-government research: Reviewing the literature, limitations, and ways forward. Government Information Quarterly, 24(3), 646-665. ISSN 0740-624X. DOI: $10.1016 /$ j.giq.2007.01.002

ZHANG, H. (2014). Analysis of the Impact of Cloud Computing Technology to Egovernment Performance Evaluation. In: Proceedings of the 2nd IEEE International Conference on Mobile Cloud Computing, Services, and Engineering (MobileCloud 2014), IEEE, pp. 295-298. ISBN 978-1-4799-2504-9. 
ZUIDERWIJK, A.; JANSSEN, M. (2013). A Coordination Theory Perspective to Improve the Use of Open Data in Policy-Making. In: Proceedings of the 12th IFIP WG 8.5 International Conference (EGOV 2013), Springer, Heidelberg, pp. 38-49. ISBN 978-3642-40358-3.

ZWATTENDORFER, B.; STRANACHER, K.; TAUBER, A.; REICHSTÄDTER, P. (2013). Cloud Computing in E-Government across Europe. In: Technology-Enabled Innovation for Democracy, Government and Governance, Springer, Berlin, pp. 181195. ISBN 978-3-642-40160-2. 
